\title{
Product perception from sensory stimuli: the case of vacuum cleaner
}

\author{
Caio Márcio Almeida e Silva ${ }^{\mathrm{a},{ }^{*}}$, Maria Lúcia R. L. Okimoto ${ }^{\mathrm{b}}$ and Raffaela Leane Zenni Tanure ${ }^{\mathrm{c}}$ \\ ${ }^{a}$ Departament of Design, Federal University of Paraná, caiomarcio1001@yahoo.com.br, General Carneiro street, \\ 460, Dom Pedro I Building, $8^{\text {th }}$ floor, Curitiba - PR, Brazil. \\ beparment of Machanical Engineering, Federal University of Paraná, lucia.demec@ufpr.br, Polytechnic Center, \\ Garden of Americas, Curitiba - PR, Brazil. \\ ${ }^{\mathrm{c}}$ Deparment of Production Engineering, Federal University of Rio Grande do Sul, raffaelat@gmail.com, Porto \\ Alegre - RS, Brazil.
}

\begin{abstract}
This paper discusses the importance of consideration of different sensory stimuli in the perception of the product. So wue conducted an experiment that examined whether there is a difference between the perception of sensory stimuli from artificially isolated. The result is an analysis of the different sensory modalities, relating them to product an between them.
\end{abstract}

Keywords: Design, evaluation, sensory stimuli

\section{Introduction}

The recognition and experience with a particular product can be performed from the stimuli registered by the senses. Usually, the stimulus more consciously used and worked by the authors is visual. As an example, we have the works of (Dondis,1997), (Wong, 1998), (Lidwell et al, 2003), (Matlin, 2004), (Arnehim, 2005) e (Krippendorff, 2006).

Nevertheless, there are some studies that consider other sensory stimuli. Schifferstein e Cleiren, 2005, for example, developed a survey to capture product experiences. This capture takes place from the perception of a sensory modality. To the authors, the experience with the product comprises: a perception that the person is interacting, the identification of the object, the cognitive associations, the active memories, the feelings that it provokes, and judgments of value that is produced.

The user experience with focus on tact was crafted by Sonneveld e Schifferstein 2008. The authors consider the tact, initially as an isolated experience. This experience, which comprises five aspects: movement, tactile properties, visceral feelings, sensations and affective behavior. The authors also discuss the meaning of touch and interaction from touch. Therefore, we present the tactile properties of the object: elasticity, hardness and plasticity, temperature, texture and patterns, shape and size of the object, and weight and balance.

Nefs (2008), on the other hand, discusses the experience of objects from the visual stimulus. To this end, the author deals with the product as a physical object and as the appearance, which are considered the following aspects: the shape, material, lighting, color and the theory of SMI triangle.

Van Egmond (2008) discusses the process of exploring an experience from the sounds of the products. For both, in the development of the project, the author proposes that the possible sound that will be used in the product is recorded, analyzed, printed a concept according to the context in which it will be used, and finally evaluated.

The combination of smell and taste with the user experience has been identified in Cardello and Wise, (2008). The authors suggest the fundamental phenomena from the taste experience. They are: adaptation of the taste, flavor repetitive experiences and preferences, a combination of taste experiences,

${ }^{*}$ Corresponding author. E-mail: caiomarcio1001@yahoo.com.br. 
modification of taste experiences, tastes and experiences of innate preferences, and effects of apprehending experience with flavors. Regarding the experience from the smell, the authors also point to the fundamental phenomena of experience from the smell. They are: olfactory adaptation, a combination of olfactory experience, modifications of the experiences of smells, and experiences and preferences from the innate smells and seized odors.

In possession of the theory of perception from different sensory stimuli, the paper aims to demonstrate how users perceive a vacuum cleaner using only a sensory stimulus. In this case, there will be conducted an experiment with them. These will have their data analyzed and discussed

Thus, the purpose of this paper is to discuss the matter from an experiment that will address the perception from one sensory modality. Initially a reasoning on the theory that considers the issue was held. Then the product was chosen to be evaluated (Consul Leve vacuum cleaner) and drafted the experiment evaluation of the product. The experiment aims to measure the identification of a product from a single sensory stimulus. Also, identify which stimulus provided a clearer identification of the product. For both, the test is divided into three stages related indicators. In addition, participants will be divided into groups, each corresponding to a sensory stimulus.

After developing a pilot test was conducted to fit the experiment. Continuing, the data collected, the experiment was performed and the results explained. Therefore, the discussion was made about the results. The collected data were processed using the ANOVA statistical test.

\section{Methodological formulation}

It was initially held a rationale on the theory that considers the matter. Then he was chosen the product you will be assessed (vacuum cleaner Consul Lightweight 1300 watts), as well as prepared the experiment of product evaluation. The experiment aims to measure the identification of a product from a single sensory stimulus, as well as identify which stimulus provided a clearer identification of the product. To this end, participants were invited at random and divided into three groups. Each group for a sensory stimulus worked.

For the implementation of the experiment, conducted in the laboratory of ergonomics and usability of Federal University of Parana, it was necessary to the vacuum 1300 watts, a Consul Lightweight visual blocker (sale) and an auditory blocker. These last two helped the participant to look for a single sensory stimulus. As metrics used in the assessment, we have the performance, as the success and errors of the task.

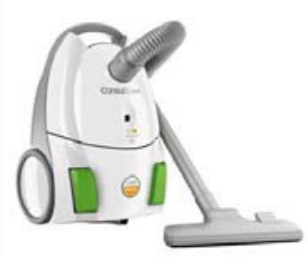

Figure 1: Vacuum cleaner Consul Lightweight 1300 watts Fonte: http://www.consul.com.br/Home/Aspiradores/Aspirador depoLeve1300W.aspx

After the development was conducted a pilot test for tuning of the experiment. In continuity, the data were collected, the experiment was conducted and the results given.

\subsection{The experiment}

The experiment was divided into four steps: a general, common to the three groups; a more specific, with emphasis for each sensory stimulation; and another end, common to the three groups.

Participants were divided into three groups: one for interaction from Visual stimuli, one concerning the interaction of auditory stimuli, and another concerning the interaction from tactile stimuli. After the unimodal interaction, applicants were asked to complete the following information:

\section{Step 1: General}

1-describe exactly, and the most detailed possible, what you noticed and felt when interacting with the product. (In the case of participants who cannot read and write, the moderator is responsible for reading and writing to the same)

2-in his opinion, were you able to identify the product from this interaction?

( ) Yes ( ) No

3- With which product you finished interact? 
Indicator for items 4 and 5: positioning the user about the interaction with the product from the particular mode

4-what was the degree of difficulty for you to identify the product?

Extremely difficult-extremely easy (semantic differential scale from a line of 10 centimeters with no visual reference)

5-to what extent this type of stimulus should influence on the use of this product?

Does not influence anything - strongly Influences (semantic differential scale from a line of 10 centimeters with no visual reference)

If influence,

Negatively influences - strongly Influences (semantic differential scale from a line of 10 centimeters with no visual reference)

Next, participants were invited to make their "Yes" or "no" as a response to the comments submitted. The categories are not specified for the evaluated. As an indicator for the four statements, is the recognition of all of the product from the unimodal interaction.

\begin{tabular}{|l|l|l|l|}
\hline Yes & No & Comments & Categories \\
\hline & $\begin{array}{l}\text { I find the product that } \\
\text { interaction small com- } \\
\text { pared to my hand. }\end{array}$ & Size \\
\hline & $\begin{array}{l}\text { I find the product that } \\
\text { interaction apparently } \\
\text { less powerful than a } \\
\text { bike. }\end{array}$ & Power \\
\hline & $\begin{array}{l}\text { I find the product that } \\
\text { interaction lighter than a } \\
\text { kilo. }\end{array}$ & Weight \\
\hline & $\begin{array}{l}\text { I believe the product } \\
\text { interaction is motorized. }\end{array}$ & Operation \\
\hline
\end{tabular}

Evaluation of step 1

Questions 1 and 2: qualitative assessment, from a categorization of the answers.

Question 3 test post Assessment:

Identification ( ) fully correct ( 2 points)

( ) identification partially correct (1 point)

( ) incorrect identification (no point)

Questions 4 and 5: quantitative assessment from the average of the results to the user's Placement in- dicator about the interaction with the product from the specific modality.

4 statements: evaluation from the binary "hit" and "Erred". Each correct answer is worth two points. The total of points earned from these four answers will be added to the score to question three. The result will be the input for quantitative indicatorrecognition of the entire product from the unimodal interaction.

The "evidence in product" were categorized and analyzed qualitatively.

\section{Step 2: specific recognition}

Participants were invited to make their "Yes" or "no" as a response to the comments submitted. The categories have not been specified for the participants. As an indicator for the four statements, is the recognition of the specificities of the product from the unimodal interaction. Here, we will supply you with an "x" the correct answers.

\section{Stimulu: Touth}

\begin{tabular}{|l|l|l|l|}
\hline Yes & No & Comments & Categories \\
\hline $\mathrm{x}$ & & $\begin{array}{l}\text { I find the product that inte- } \\
\text { ragi more polished. }\end{array}$ & Texture \\
\hline $\mathrm{x}$ & & $\begin{array}{l}\text { I believe the hard interac- } \\
\text { tion product. }\end{array}$ & Physical property \\
\hline $\mathrm{x}$ & $\mathrm{x}$ & $\begin{array}{l}\text { I find the product that cold } \\
\text { interaction, related to tem- } \\
\text { perature of my body. }\end{array}$ & $\begin{array}{l}\text { Temperature in } \\
\text { use }\end{array}$ \\
\hline $\mathrm{x}$ & $\begin{array}{l}\text { I find the product that inte- } \\
\text { raction heavier than a } \\
\text { pound. }\end{array}$ & Weight \\
\hline & $\mathrm{X}$ & $\begin{array}{l}\text { I find the product that inte- } \\
\text { raction has a more straight. }\end{array}$ & Form \\
& $\begin{array}{l}\text { I believe that the product } \\
\text { carry over a distance of 10 } \\
\text { meters. }\end{array}$ & Transport \\
\hline
\end{tabular}

\section{Estímulo: Hearing}

\begin{tabular}{|l|l|l|l|}
\hline Yes & No & Comments & Categories \\
\hline $\mathrm{x}$ & $\mathrm{x}$ & $\begin{array}{l}\text { I find the product that ap- } \\
\text { proximate interaction. }\end{array}$ & Sound typology \\
\hline $\mathrm{x}$ & $\begin{array}{l}\text { I believe that the product } \\
\text { that interaction produces } \\
\text { noise, rather than a voice } \\
\text { recording. }\end{array}$ & Sound typology \\
$\begin{array}{l}\text { I believe that the whole } \\
\text { process of product use that } \\
\text { interaction is with the firing } \\
\text { of just one command. (e.g. }\end{array}$ & Stages of use \\
\hline
\end{tabular}




\begin{tabular}{|l|l|l|l|}
\hline & & bind $\mid$ off $)$ & \\
\hline $\mathrm{x}$ & $\begin{array}{l}\text { I consider the sound pro- } \\
\text { duced by the product that } \\
\text { interaction is associated to } \\
\text { the different functions of } \\
\text { use. (e.g. a washing clothes } \\
\text { has the following functions } \\
\text { use: washing, rinsing and } \\
\text { centrifuging) }\end{array}$ & \\
\hline $\mathrm{x}$ & $\begin{array}{l}\text { I believe that the prod- } \\
\text { uct that would provide a } \\
\text { direct contact with me } \\
\text { interaction if I used it. }\end{array}$ & Interaction \\
\hline
\end{tabular}

\section{Stimulus: Vision}

\begin{tabular}{|c|l|l|l|}
\hline Yes & No & Comments & Categories \\
\hline $\mathrm{X}$ & $\mathrm{x}$ & $\begin{array}{l}\text { I find the product that I } \\
\text { interected has a more } \\
\text { straight. }\end{array}$ & Form \\
\hline $\mathrm{X}$ & & $\begin{array}{l}\text { I find the product that I } \\
\text { interected lighter than a } \\
\text { kilo. }\end{array}$ & Weight \\
\hline $\mathrm{X}$ & $\begin{array}{l}\text { I believe that the product } \\
\text { thar I interected is hard. }\end{array}$ & $\begin{array}{l}\text { Physical } \\
\text { property }\end{array}$ \\
\hline $\mathrm{X}$ & $\begin{array}{l}\text { I find the shape of the } \\
\text { product is associated with } \\
\text { its function (s). (e.g. If the } \\
\text { shape of a door knob indi- } \\
\text { cates that it should be } \\
\text { pulled) }\end{array}$ & $\begin{array}{l}\text { Association } \\
\text { of form }\end{array}$ \\
\hline $\mathrm{x}$ & $\begin{array}{l}\text { I believe that the product } \\
\text { that I interected would not } \\
\text { provide a direct contact } \\
\text { with me if I used it. }\end{array}$ & $\begin{array}{l}\text { Interaction } \\
\text { I believe that the product } \\
\text { that I interected is difficult } \\
\text { to carry over a distance of } \\
\text { 10 meters. }\end{array}$ & Transport \\
\hline
\end{tabular}

\begin{tabular}{|l|l|l|l|}
\hline Yes & No & \multicolumn{1}{|c|}{ Comments } & Categories \\
\hline 1 & 29 & $\begin{array}{l}\text { I find the product that inte- } \\
\text { raction small compared to } \\
\text { my hand. }\end{array}$ & Size \\
\hline 30 & $\mathbf{0}$ & $\begin{array}{l}\text { I find the product that inte- } \\
\text { raction apparently less } \\
\text { powerful than a bike. }\end{array}$ & Power \\
\hline 6 & 24 & $\begin{array}{l}\text { I find the product that inte- } \\
\text { raction lighter than a kilo. }\end{array}$ & Weight \\
\hline 30 & $\mathbf{0}$ & $\begin{array}{l}\text { I believe the product inte- } \\
\text { raction is motorized. }\end{array}$ & Operation \\
\hline
\end{tabular}

\section{Evaluation of step 2}

Evaluations for the tact and vision, each account will match correct 1.67 points. Thus, the sum of six correct considerations will total in 10 points. With regard to the hearing, each correct account will match
2.0 points. Soon, the sum of five considerations will total in 10 points.

\section{Step 3: Final}

In this step participants related the experience of the product with its functionality. To this end, they will have to choose alternatives that relate to the product. Participants can choose how many alternatives are necessary.

From the interaction with the product, you would conclude that the product to seve ... [Adapted from Sonneveld e Schifferstein (2008)]

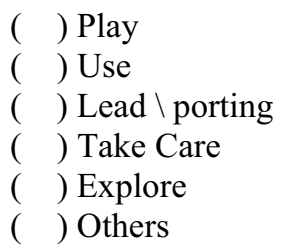

\section{Evaluation of step 3}

The result will bring the categories most cited in the various methods. This will bring elements for discussion.

\subsection{Tab data}

\section{Step 1: Geral}

- In his opinion, were you able to identify the product from this interaction?

26 participants responded that Yes, and 4 replied that failed. The partial, divided by group, are as follows: tato (yes | no: $8: 2$ ), hearing (yes $\mid$ no: $8: 2$ ), and vision (10: Yes $\mid$ No: 0)

- With which product you finished interact?

For this, questioning 25 people responded that it was a vacuum cleaner; 4 people replied that it was a washing machine; 1 person associated to an object of medical use.

Next, we will present the sum of answers of the table that has recognition as indicator of all of the product from the unimodal interaction. The summations in green color correspond to that agreed the answers. Already the red, correspond to that wrong answers.

Total 113 correct answers. They were multiplied by 2.5 (pre-set value) and divided by 30 (number of participants). Thus the recognition indicator of all of 
the product from the unimodal won 9.42 interaction points.

\section{Step 2: Specific}

Here will be repeated the same procedure in the preceding table, where the correct answers were presented in green color, and the incorrect were presented in red.

\section{Stimulu: Touth}

\begin{tabular}{|l|l|l|l|}
\hline Yes & No & Comments & Categories \\
\hline $\mathbf{0}$ & $\mathbf{1 0}$ & $\begin{array}{l}\text { I find the product that I } \\
\text { interected more polished. }\end{array}$ & Texture \\
\hline $\mathbf{1 0}$ & $\mathbf{0}$ & $\begin{array}{l}\text { I believe that the product } \\
\text { thar I interected is hard. }\end{array}$ & Physical property \\
\hline 7 & $\mathbf{3}$ & $\begin{array}{l}\text { I find the product that cold } \\
\text { interact, related to tempera- } \\
\text { ture of my body. }\end{array}$ & $\begin{array}{l}\text { Temperature in } \\
\text { use }\end{array}$ \\
\hline $\mathbf{6}$ & $\mathbf{4}$ & $\begin{array}{l}\text { I find the product that inte- } \\
\text { ract heavier than a pound. }\end{array}$ & Weight \\
\hline $\mathbf{4}$ & $\mathbf{6}$ & $\begin{array}{l}\text { I find the product that inte- } \\
\text { ract has a more straight. }\end{array}$ & Form \\
\hline $\mathbf{1}$ & $\mathbf{9}$ & $\begin{array}{l}\text { I believe that the product } \\
\text { that I interacted is difficult } \\
\text { to carry over a distance of } \\
10 \text { meters. }\end{array}$ & Transport \\
\hline
\end{tabular}

Total of 48 correct answers. They were multiplied by 1.67 (pre-set value) and divided by 10 (number of participants). Thus, the recognition of the specificities of the product from the unimodal interaction (touch-specific) obtained 8.02 points.

\section{Estímulo: Hearing}

Here will be repeated the same procedure in the preceding table, where the correct answers were presented in green color, and the incorrect were presented in red.

\begin{tabular}{|l|l|l|l|}
\hline Yes & No & Comments & Categories \\
\hline $\mathbf{0}$ & $\mathbf{1 0}$ & $\begin{array}{l}\text { I find the product that approximate } \\
\text { interaction. }\end{array}$ & $\begin{array}{l}\text { Sound } \\
\text { typology }\end{array}$ \\
\hline 10 & $\mathbf{0}$ & $\begin{array}{l}\text { I believe that the product that inte- } \\
\text { raction produces noise, rather than a } \\
\text { voice recording. }\end{array}$ & $\begin{array}{l}\text { Sound } \\
\text { typology }\end{array}$ \\
\hline $\mathbf{0}$ & $\mathbf{1 0}$ & $\begin{array}{l}\text { I believe that the whole process of } \\
\text { product use that interaction is with }\end{array}$ & $\begin{array}{l}\text { Estágios de } \\
\text { uso }\end{array}$ \\
\hline
\end{tabular}

\begin{tabular}{|l|l|l|l|}
\hline 7 & 3 & $\begin{array}{l}\text { the firing of just one command. } \\
\text { (e.g. bind } \mid \text { off) }\end{array}$ & \\
\hline 7 & $\begin{array}{l}\text { I consider the sound produced by } \\
\text { the product that interaction is asso- } \\
\text { ciated to the different functions of } \\
\text { use. (e.g. a washing clothes has the } \\
\text { following functions use: washing, } \\
\text { rinsing and centrifuging) }\end{array}$ & Stages of \\
use \\
\hline 9 & 1 & $\begin{array}{l}\text { I believe that the product that would } \\
\text { provide a direct contact with me } \\
\text { interaction if I used it. }\end{array}$ & Interaction \\
\hline
\end{tabular}

Total of 46 correct answers. They were multiplied by 2.0 (pre-set value) and divided by 10 (number of participants). Thus, the recognition of the specificities of the product from the unimodal interaction (specific hearing) obtained 9.2 points.

\section{Stimulus: Vision}

\begin{tabular}{|l|l|l|l|}
\hline Yes & No & Comments & Categories \\
\hline 7 & $\mathbf{3}$ & $\begin{array}{l}\text { I find the product that I interected } \\
\text { has a more straight. }\end{array}$ & Form \\
\hline $\mathbf{1}$ & $\mathbf{9}$ & $\begin{array}{l}\text { I find the product that I interected } \\
\text { lighter than a kilo. }\end{array}$ & Weight \\
\hline $\mathbf{1 0}$ & $\mathbf{0}$ & $\begin{array}{l}\text { I believe that the product thar I } \\
\text { interected is hard. }\end{array}$ & $\begin{array}{l}\text { Physical } \\
\text { property }\end{array}$ \\
\hline $\mathbf{1}$ & $\mathbf{1}$ & $\begin{array}{l}\text { I find the shape of the product is } \\
\text { associated with its function (s). } \\
\text { (e.g. If the shape of a door knob } \\
\text { indicates that it should be pulled) }\end{array}$ & $\begin{array}{l}\text { Association } \\
\text { of form }\end{array}$ \\
\hline $\mathbf{1}$ & $\mathbf{9}$ & $\begin{array}{l}\text { I believe that the product that I } \\
\text { interected would not provide a } \\
\text { direct contact with me if I used it. }\end{array}$ & Interaction \\
\hline $\mathbf{2}$ & $\mathbf{8}$ & $\begin{array}{l}\text { I believe that the product that I } \\
\text { interected is difficult to carry } \\
\text { over a distance of 10 meters. }\end{array}$ & Transport \\
\hline
\end{tabular}

Total of 52 correct answers. They were multiplied by 1.67 (pre-set value) and divided by 10 (number of participants). Thus, the recognition of the specificities of the product from the unimodal interaction (specific vision) obtained 8.68 points.

From the results of the test, it is suggested that two comparisons using statistical tests. The first indicator relates the "recognition of the whole product from unimodal interaction", which had a total of 9.42 points, with the bookmark "recognition of the specificities of the product from the unimodal interaction", which took an average of 8.63 points (considering the average of the three groups together). The second suggested comparison search list the inputs of quan- 
titative indicator "recognition of the specificities of the product from the unimodal interaction" between the three groups (tato: 8.02 hearing: 9.20 vision: 8.68 points).

\section{Step 3: Final}

From the interaction with the product, the participants had to opine "what is the product" ... [Adapted from Sonneveld e Schifferstein (2008)]
( 0 ) Play
( 27 ) Use
( 0 ) Lead $\backslash$ porting
( 0 ) Take Care
( 1 ) Explore
( 2 ) Others

\subsection{Application of analysis of variance. ANOVA}

From the results, tables were developed with the results specified for each participant. Thus, we have a table with the results of step 1 , for the recognition indicator of all of the product from the unimodal interaction.

Table 1: Results of step 1 .

SOURCE: organized by the authors (2011)

\begin{tabular}{lll}
\hline Participant & Hit & Grade \\
\hline 1 & 4 & 10 \\
\hline 2 & 4 & 10 \\
\hline 3 & 4 & 10 \\
\hline 4 & 3 & 7.5 \\
\hline 5 & 4 & 10 \\
\hline 6 & 4 & 10 \\
\hline 7 & 4 & 10 \\
\hline 8 & 4 & 10 \\
\hline 9 & 4 & 10 \\
\hline 10 & 4 & 10 \\
\hline 11 & 4 & 10 \\
\hline 12 & 3 & 7.5 \\
\hline 13 & 4 & 10 \\
\hline 14 & 3 & 7.5 \\
\hline 15 & 3 & 7.5 \\
\hline 16 & 4 & 10 \\
\hline 17 & 4 & 10 \\
\hline 18 & 4 & 10 \\
\hline 19 & 4 & 10 \\
\hline 20 & 4 & 10 \\
\hline 21 & 4 & 10 \\
\hline 22 & 3 & 7.5 \\
\hline 23 & 4 & 10 \\
\hline 24 & 4 & 10 \\
\hline 25 & 4 & 10 \\
\hline 26 & 4 & 10 \\
\hline 27 & 3 & 7.5 \\
\hline 28 & 4 & 10 \\
\hline 29 & 3 & 7.5 \\
\hline 30 & 4 & 10 \\
\hline Média total & & $\mathbf{9 . 4 2}$ \\
\hline & \\
\hline
\end{tabular}

Was developed, also, a table with the results of step two, which has as an indicator the recognition of the specificities of the product from the unimodal interaction.
Table 2: Results of step 2. SOURCE: organized by the authors (2011)

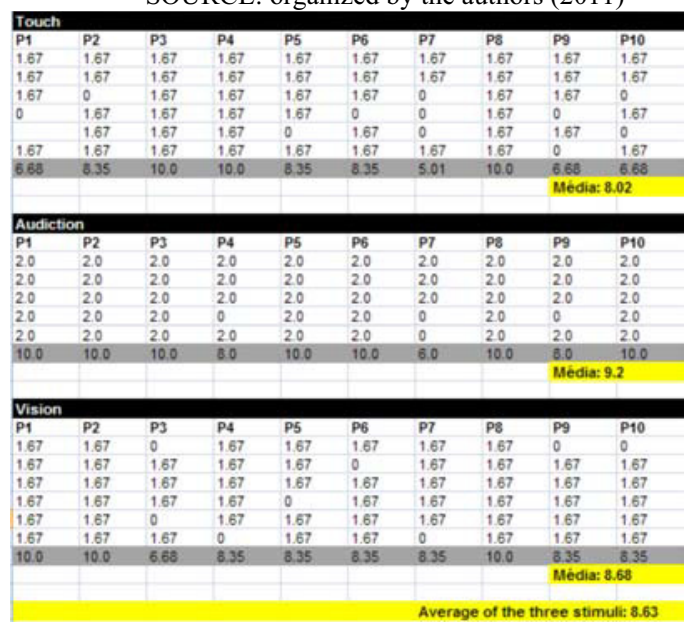

Soon, two comparisons using the test of variance analysis with $95 \%$ reliability. The first indicator relates the "recognition of the whole product from unimodal interaction" with the bookmark "recognition of the specificities of the product from the unimodal interaction" (considering the three groups together). The result of the distribution of $\mathrm{F}$ as Snedcor was 4.64. As the distribution table of $F$ as Snedcor, we identified that the amount shown above, for being greater than 4.18 , resulted in the existence of statistical difference.

The second suggested comparison search list the inputs of quantitative indicator "recognition of the specificities of the product from the unimodal interaction" between the three. The result of the distribution of $\mathrm{F}$ as Snedcor was 1.13. As the distribution table of $\mathrm{F}$ as Snedcor, we identified that the amount shown above, for being less than 4.25 , resulted in the absence of statistical difference.

From these results, we identified there was no difference between the recognition of the whole product, in step 1, and the recognition of specific parts, in step 2. On the other hand, contrary to popular thought, the hegemony of the visual interaction not proved strong enough to promote a statistical difference between it and the tactile and auditory interactions. Soon, we check for that product in the context of this experiment, the interaction from a single sensory stimulus proved quantitatively next. This idea is reinforced by the outcome of the third step which indicates that 27 participants suggested that the product was to be used, such as the vacuum cleaner.

Another aspect to be considered is that this product has at least one striking feature in every aspect. These were identified from the verbalization. There- 
fore, the product proved remarkable hose in tactile interaction, the noise of the engine has been striking in auditory interaction, and the format that shipped with the mental model of a vacuum cleaner if made remarkable visual interaction.

\section{Final Considerations}

The paper dealt with the consideration of different sensory stimuli in the perception of the product. For both, was performed an experiment that examined whether there is a difference between the perception from sensory stimuli artificially isolated. As a result, he was presented an analysis of the different sensory modalities, relating them to the product and between them.

Test results of analysis of variance showed that there is no statistical difference between General and recognition of the specificities of the product. Furthermore, it was verified that there is no statistical difference when acknowledgments were related to the specificities of the product from different sensory stimuli.

For future researches we suggest that the interaction of sensory stimuli is not just measured, and Yes, understood. To this end, it is suggested the implementation of qualitative evaluation methods.

\section{References}

[1] R. Arnheim. Arte e percepção visual, Nova versão, São Paulo, Pioneira, 2005.

[2] A. V. Cardello and P. M. Wise. Taste, smell and chemesthesis in product experience, In: Product Experience, Oxford: Elsevier (2008).

[3] W. Cybis and A. Bertiol. Ergonomia e usabilidade: conhecimentos, métodos e aplicações. São Paulo, Novatec Editora, 2007.

[4] D. A. Dondis. Sintaxe da linguagem visual. $2^{a}$ edição. São Paulo, Martins Fontes, 1997.

[5] K. Krippendorff. The semantic turn. Boca Raton, Taylor \& Francis Group, 2006.

[6] L. Lidwell, K. Holden. B. Jill. Princípios Universais do Design. Porto Alegre, Bookman, 2010.

[7] H. T. Neefs. On the visual appearance of objects. In: Product Experience. Oxford, Elsevier, 2008.

[8] J. Nielsen. Usability engineering. Boston, Academic Press, 1993.

[9] D. A. Norman. O Design do dia-a-dia. Rio de janeiro, Rocco, 2006.

[10] H. N J. Schipperstein and P. Hekkert. Product Experience. Elsevier, 2008.

[11] H. N J. Schipperstein; M. P. H. D. Cleiren. Capturing product experiences: a split-modality approach. In: Acta Psychologica 118. Elsevier, p. 293-318, 2005.

[12] Silva, C. M. A. Intuitividade no uso de produtos: proposição de um procedimento de avaliação no âmbito do design. Projeto de pesquisa. Curitiba, 2011.

[13] M. H. Sonneveld and H. N. J. e Schifferstein, H. N. J. The tactual experience of objects. In: Product Experience. Oxford: Elsevier, 2008.

[14] R. Van EgmondVAN. The experience of product sounds. In: Product Experience, Oxford: Elsevier, (2008).

[15] Van Hout, M. (2004). Interactive Products and User Emotions. Dissertação de mestrado. Twente.

[16] M. Van Hout. Interactive Products and User Emotions. Dissertação de mestrado. Twente.

[17] Princípios de Forma e Desenho. São Paulo: Editora Martins Fontes.

[18] M. Wong. Princípios de Forma e Desenho. São Paulo: Editora Martins Fontes. 